\title{
CIRCULATING IL-10 LEVELS IN CAROTID ARTERY DISEASE
}

Milos Stankovic ${ }^{1}$, Biljana Ljujic ${ }^{2}$, Djordje Radak ${ }^{3}$, Slobodanka Mitrovic ${ }^{4}$, Srdjan Babic ${ }^{3}$, Nebojsa Arsenijevic ${ }^{5}$, Miodrag Lukic ${ }^{5}$ and Nada Pejnovic ${ }^{6}$

${ }^{1}$ Department of Surgery. Clinical Center Kragujevac, Kragujevac, Serbia

${ }^{2}$ Department of Genetics, Faculty of medical sciences, University of Kragujevac, Kragujevac, Serbia

${ }^{3}$ Dedinje Cardiovascular Institute, School of Medicine, University of Belgrad, Belgrade, Serbia

${ }^{4}$ Department of pathology, Faculty of medical sciences, University of Kragujevac, Kragujevac, Serbia

${ }^{5}$ Center for Molecular Medicine and Stem Cell Research, Faculty of Medical Sciences, University of Kragujevac, Kragujevac, Serbia

${ }^{6}$ Department of pathophysiology, Faculty of medical sciences, University of Kragujevac, Kragujevac, Serbia

\section{CIRIULIŠUĆI IL-10 NIVOI U BOLESTI ARTERIJE IKAROTIDA \\ Miloš Stanković ${ }^{1}$, Biljana Ljujić ${ }^{2}$, Đorđe Radak ${ }^{3}$, Slobodanka Mitrovićc ${ }^{4}$, Srđan Babić ${ }^{3}$, Nebojša Arsenijević ${ }^{5}$, Miodrag Lukić ${ }^{5}$ i Nada Pejnović ${ }^{6}$ ${ }^{1}$ Klinika za hirurgiju, Klinički centar Kragujevac, Kragujevac, Srbija \\ ${ }^{2}$ Katedra za genetiku, Fakultet medicinskih nauka, Univerzitet u Kragujevcu, Kragujevac, Srbija ${ }^{3}$ Kardiovaskularni institut Dedinje, Medicinski fakultet, Univerzitet u Beogradu, Beograd, Srbija \\ ${ }^{4}$ Katedra za patologiju, Fakultet medicinskih nauka, Univerzitet u Kragujevcu, Kragujevac, Srbija \\ ${ }^{5}$ Centar za molekulsku medicinu i istraživanje matičnih ćelija, Fakultet medicinskih nauka, Univerzitet u Kragujevcu, Kragujevac, Srbija \\ ${ }^{6}$ Katedra za patofiziologiju, Fakultet medicinskih nauka, Univerzitet u Kragujevcu, Kragujevac, Srbija}

Received / Primljen: 03. 07. 2017

Accepted / Prihvaćen: 16. 07. 2017

\section{ABSTRACT}

Carotid atherosclerosis may be associated with neurosymptoms including cerebral infarction. IL-10 exerts atheroprotective effects, but its role in carotid disease is not fully defined. We aimed to investigate serum IL-10 levels in patients undergoing endarterectomy and their relation to the degree of carotid stenosis, plaque types and neurosymptoms.

Two hundred consecutive patients with atherosclerotic carotid stenosis and 29 healthy controls were enrolled in this study. Plaque types were classified according to AHA criteria. Serum IL-10 levels were determined by ELISA.

Patients undergoing endarterectomy had significantly higher circulating IL-10 levels $(18.7 \pm 3.2 \mathrm{pg} / \mathrm{ml})$ in comparison with healthy controls $(7.2 \pm 1.8 \mathrm{pg} / \mathrm{ml} ; \mathrm{P}=0.0001)$ and $\mathrm{IL}$ 10 has good discriminatory efficacy between these two groups (ROC curve, $A U C=0.723, P=0.0001$ ). Patients with $<70 \%$ and those with $>70 \%$ of carotid stenosis did not differ in terms of age, sex, cardiovascular risk factors except hypertension, neurosymptoms and AHA plaque types. Circulating IL-10 levels differed significantly among patients with different carotid plaque types $(P=0.002)$. Patients with uncomplicated plaques had significantly higher serum levels of IL-10 (23.0 \pm $6.1 \mathrm{pg} / \mathrm{ml}$ ) compared to those with complicated plaques $(13.0$ $\pm 1.4 \mathrm{pg} / \mathrm{ml}, P=0.035)$ and $I \mathrm{~L}-10$ can differentiate patients between these two groups (ROC curve, $A U C=0.413, P=0.035$ ).

Our findings reveal an important role for IL-10 in carotid atherosclerosis. IL-10 might be a potential biomarker in discriminating patients with carotid disease from healthy controls. Decreased serum levels of IL-10 are related to complicated carotid plaques.

Keywords: carotid disease, atherosclerotic plaque, cytokines, $I L-10$

\section{SAŽETAK}

Karotidna bolest se manifestuje aterosklerotskim suženjem karotidnih arterija $i$ može biti udružena sa neurosimptomima. IL-10 ispoljava atero-protektivna dejstva, ali njegova uloga u karotidnoj bolesti nije u potpunosti ispitana. Cilj studije je bio ispitivanje nivoa IL-10 u serumu bolesnika podvrgnutih endarterektomiji sa različitim tipovima karotidnih plakova, stepenima karotidne stenoze i neurosimptomima.

U studiju je bilo uključeno 200 bolesnika sa aterosklerotskom stenozom karotidne arterije i 29 zdravih osoba. Aterosklerotski plakovi su klasifikovani prema AHA kriterijumima. Serumske koncentracije IL-10 su odredivane ELISA metodom.

Bolesnici podrvgnuti endarterektomiji su imali značajno više serumske vrednosti IL-10 $(18.7 \pm 3.2 \mathrm{pg} / \mathrm{ml})$ u poređenju sa zdravim kontrolama $(7.2 \pm 1.8 \mathrm{pg} / \mathrm{ml} ; P=0.0001)$ i serumski IL-10 može da diskriminiše zdrave osobe i bolesnike sa karotidnom bolesti (ROC kriva, AUC =0.723, P=0.0001). Bolesnici sa stepenom stenoze karotidne arterije $<70 \% i$ $>70 \%$ se nisu razlikovali u odnosu na pol, starost, kardiovaskularne rizikofaktore izuzev hipertenzije, neurosimptome i tip plaka. Serumski IL-10 se značajno razlikuje izmedu bolesnika sa različitim tipovima aterosklerotskog plaka $(P=0.002)$. Bolesnici sa nekomplikovanim plakom su imali značajno više vrednosti serumskog IL-10 (23.0 $\pm 6.1 \mathrm{pg} / \mathrm{ml})$ u odnosu na bolesnike sa komplikovanim plakom (13.0 \pm 1.4 $\mathrm{pg} / \mathrm{ml}, \mathrm{P}=0.035)$. Cirkulišući IL-10 može da diferencira bolesnike sa komplikovanim plakovima od onih sa nekomplikovanim plakom (ROC kriva; $A U C=0.413, P=0.035$ ).

Dobijeni rezultati pokazuju značajnu ulogu IL-10 u aterosklerotskoj karotidnoj bolesti. Serumski IL-10 može biti potencijalni biomarker za razlikovanje bolesnika sa karotidnom bolešću od zdravih osoba. Niži nivoi IL-10 su povezani sa prisustvom komplikovanih plakova.

Ključne reči: karotidna bolest, aterosklerotski plak, citokini, IL-10 Tel: +38134360800; Fax: +38134360800 Email: nadap@medf.kg.ac.rs 


\section{ABBREVIATIONS}

AHA - American Heart Association CAD - coronary artery disease CEA - carotid endarterectomy ICA - internal carotid artery IL - Interleukin IFN- $\boldsymbol{\gamma}$ - Interferon - gamma
MDCT - multi-detector computerized tomography PAD - peripheral artery disease

ROC - Receiver's operating characteristic curve

TIA - transient ischemic attacks

TNF- $\boldsymbol{\alpha}$ - tumor necrosis factor-alpha

\section{INTRODUCTION}

Atherosclerosis is a chronic inflammatory disease of arterial blood vessels leading to complications including stroke and myocardial infarction (1). Atherosclerosis is systemic inflammatory disease that is initiated and regulated by cells of the immune system. Plaques are formed when lipoproteins are deposited at specific sites of the arterial vessel walls through intimal inflammation, necrosis, fibrosis, and calcification (2). Carotid plaques may cause narrowing of blood vessel lumen or they may rupture causing thrombosis and life threatening clinical disease. Carotid disease is typically manifested as atherosclerotic stenosis and may be associated with neurological complications including amaurosis fugax, transient ischemic attacks (TIAs) and cerebral infarction. Plaques prone to rupture have thin fibrous cap and are classified as unstable or vulnerable plaques, while those with thick fibrous cap, less inflammation and small lipid and necrotic core are stable plaques. Complicated plaques are defined when they have features including intraplaque calcification, hemorrhage, thrombi or plaque erosion.

The precise molecular and cellular mechanisms underlying carotid plaque formation are incompletely defined. Intraplaque expression of cytokines or their circulating levels are associated with vascular events and the stage of atherosclerotic disease (3). Circulating levels of inflammatory biomarkers, including high-sensitivity Creactive protein (hs-CRP), interleukin (IL)-6, tumor necrosis factor- $\alpha$ (TNF- $\alpha$ ) or interleukin (IL)-18 are predictive for vascular events (4-7), carotid plaque vulnerability and higher intima-media thickness $(8,9)$. In contrast, elevated serum levels of the anti-inflammatory cytokine interleukin (IL)-10 and Th2 cytokine interleukin (IL)-5 are associated with a favorable prognosis of atherosclerotic disease $(10,11)$.

IL-10, a type II cytokine, was initially described by Mosmann, Fiorentino and Bond in 1989, as a cytokine that inhibits synthesis and excretion of proinflammatory cytokines by Th1 lymphocytes (12). Its main biological action is inhibition of presentation of antigens by dendritic cells and macrophages to Th1 cells, through inhibition of MHC class II expression, as well as costimulatory molecules expression (13-16). In this way antigen presenting cells are deprived of stimuli to synthesize and excrete Th1 associated cytokines (IL-2, IFN- $\gamma$ ). IL-10 also inhibits synthesis of proinflammatory cytokines by macrophages and dendritic cells including
IL-1, IL-6, IL-12, and TNF $\alpha$. Furthermore, it inhibits inflammation by increasing the release of IL-1 receptor antagonist by macrophages (17-19). However, not all effects of IL-10 are immunosuppressive as IL-10 costimulates B-cell activation, influences immunoglobulin class-type switching, and prolongs survival of B-cells (20).

Most experimental data confirms atheroprotective role of IL-10 in animal models of atherosclerosis (21-25). The results obtained in experimental animal models, where atherosclerosis is result of certain experimental conditions may be opposing to the studies emerging from patients with atherosclerosis that can be influenced by various genetic and environmental factors.

We investigated serum levels of IL-10 in 199 patients submitted to elective carotid endarterectomy. Patients were grouped according to the degree of carotid stenosis, determined by color duplex scan of carotid arteries, those with carotid stenosis less or equal to $70 \%$, and those with atherosclerotic plaques that narrowed carotid arteries more than $70 \%$. We analyzed the association of circulating IL-10 levels with the grade of carotid stenosis, histologic features of carotid plaques and neurosymptoms.

\section{PATIENTS AND METHODS}

\section{Study population}

We enrolled 200 consecutive surgical patients with atherosclerotic carotid stenosis, admitted to IKVB Dedinje for carotid endarterectomy. Color Doppler scan and MDCT (multi-detector computerized tomography) were performed on each patient, to obtain information on a degree of carotid stenosis. We used North American Symptomatic Carotid Endarterectomy Trial criteria to define the level of stenosis of carotid artery. The patients selected for this operation were either symptomatic, or asymptomatic. Symptomatic patients, 99 of entire group, had in their previous medical history some form of neurological incident, weather as transient ischemic attack (TIA), amaurosis fugax (AFX) or stroke, regardless of the degree of stenosis at the time of surgery.

Blood samples were obtained from 200 patients who underwent surgery, prior to the surgery. We also collected blood from 29 healthy volunteers. 
Blood samples were collected from patients by a single needle stick. Sera were separated, aliquoted and stored at $-20^{\circ} \mathrm{C}$ until assayed.

\section{Histopathologic analysis of carotid atherosclerotic plaques}

Atherosclerotic plaques removed from patient's carot id artery were immediately frozen, and then submitted for further histological examination. The frozen samples were cut into sections of $5 \mu \mathrm{m}$ thicknesses and stained using a hematoxylin eosin staining by standard procedure (26). After the staining all sections were examined using the Olympus BX41 microscope. The grade of atherosclerosis in observed plaques was established according to the classification of the American Heart Association Committee on Vascular Lesions of the Council of Atherosclerosis (27).

The evaluation of plaques stability was performed according to the criteria as previously described $(28,29)$. Stable plaques (fibrous plaques and fibroatheroma) had low lipid content, thick fibrous cap, low level of inflammation and absence of plaque complications. Briefly, all

A
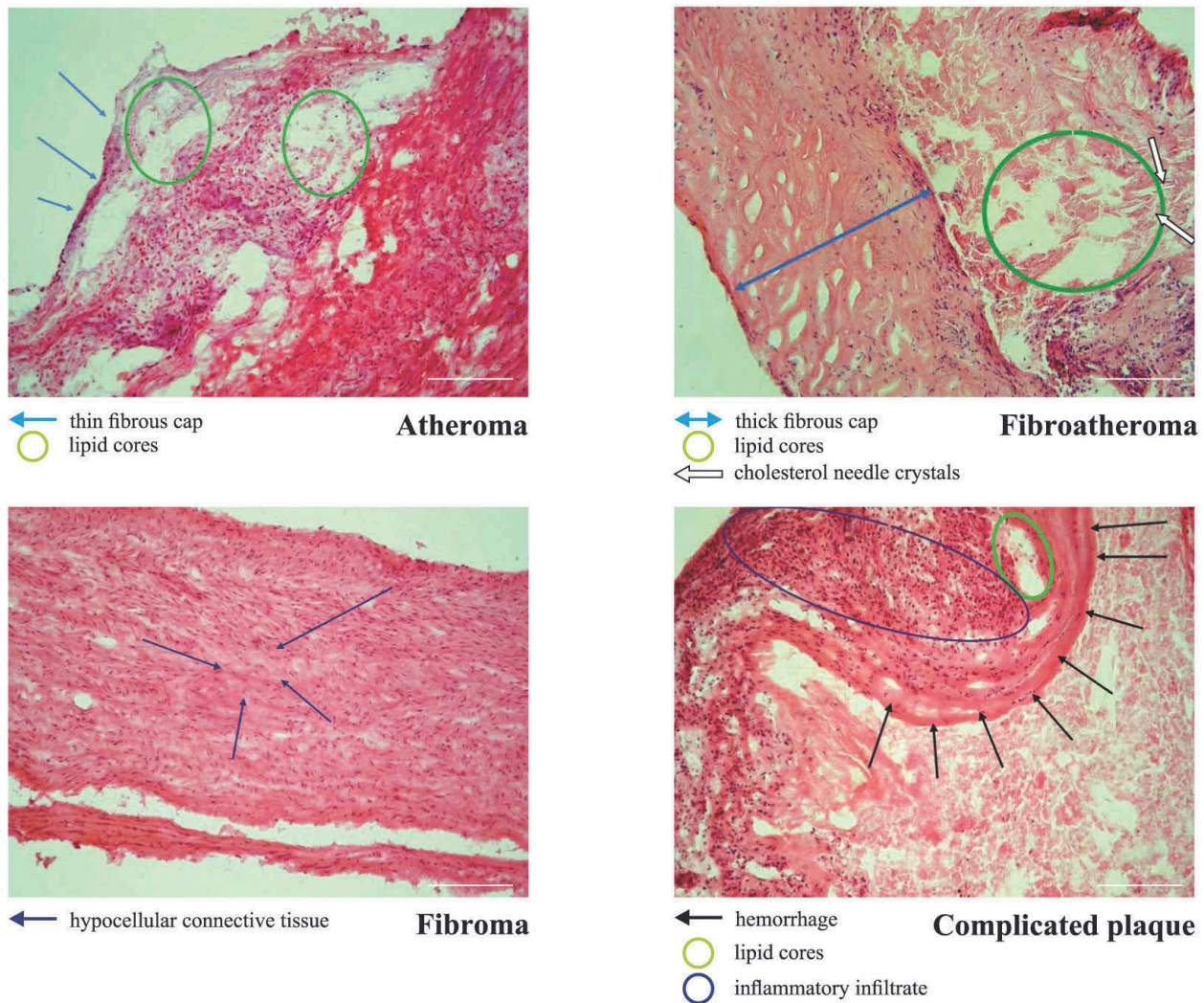

B

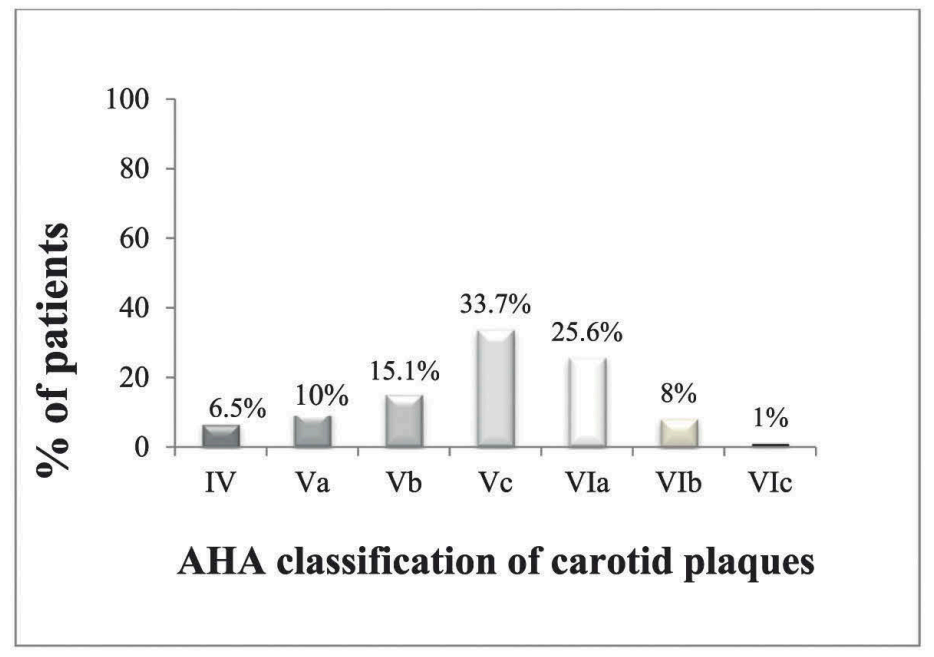

Figure 1. AHA classification of carotid plaques in studied population

A. Representative images of carotid plaque types

B. Proportions of patients with carotid disease with different types of plaques according to AHA criteria 
Table 1. Demographic, clinical and histological characteristics of patients undergoing endarterectomy

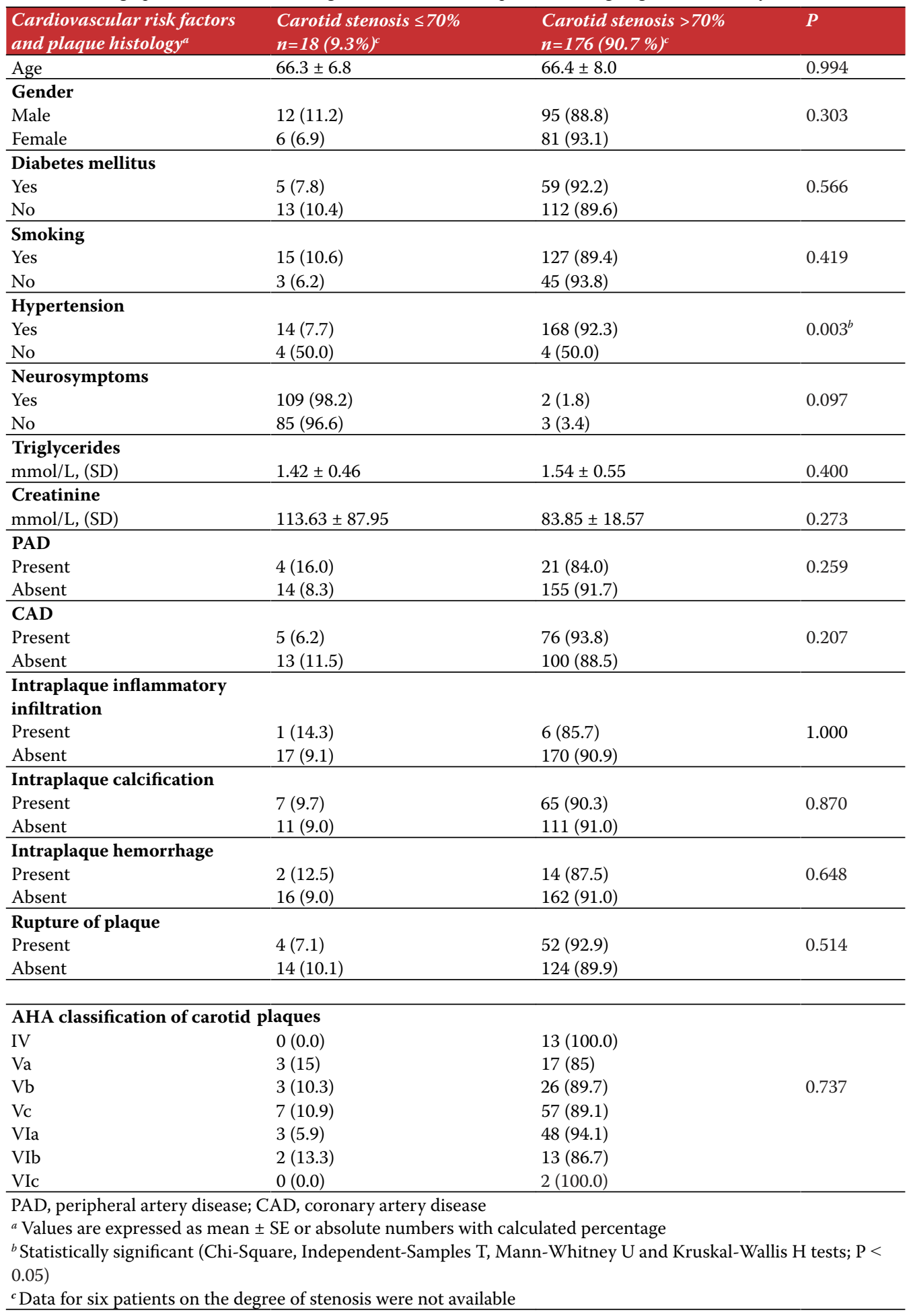

other plaques contained large, lipid-rich necrotic core with a thin and inflamed cap ( $<65 \mu \mathrm{m}$ of thickness) and other features such as expansive remodeling, plaque hemorrhage, neovascularization, adventitial inflammation, and "spotty" calcifications. The evaluation of plaque stability was done by two independent investigators in a blinded fashion (S.M., I.T.).

Carotid plaques were classified as complicated (fibroatheroma with calcifications $\mathrm{Vb}$, ruptured atheroma with calcifications VIa, fibroatheroma with hemorrhage VIb, ruptured atheroma with thrombus VIc) or uncomplicated plaques (atheroma IV, fibroatheroma Va and fibrotic plaques Vc).

\section{Quantification of IL-10 in sera}

Cytokine levels were measured using highly sensitive enzyme-linked immunosorbent assay (ELISA) kits (R\&D 
Systems Minneapolis, MN) specific for the human IL-10 according to the manufacturer's instruction. The standard stock was serially diluted in Reagent Diluent to generate seven points for the standard curves. After incubation with diluted sera and standards, $100 \mu \mathrm{l}$ of the Detection Antibody was added to each well and incubated for 2 hours at room temperature followed by Streptavidin-HRP $(100 \mu \mathrm{l})$. The incubation was terminated after $20 \mathrm{~min}$ at room temperature and $100 \mu \mathrm{l}$ of Substrate Solution was added. Then, $50 \mu \mathrm{l}$ of Stop Solution was added to each well, and the optical density of each well was immediately determined using a microplate reader. Absorbance was measured on ZENYTH 3100 apparatus, at $590 \mathrm{~nm}$, and obtained data was then processed by Software for Anthos Multimode Detectors. The results were expressed in $\mathrm{pg} / \mathrm{ml}$. (30).

\section{Statistical analysis}

Results are expressed as median and ranges (25 and 75 percentiles) or mean \pm SE. Clinical and plaque histological features were compared between groups of patients with $>70 \%$ or $<70 \%$ of carotid artery stenosis by $x^{2}$ test. The Kruskal-Wallis and Mann-Whitney non-parametric tests or independent Student $\mathrm{t}$-test were used to investigate the significance of differences between groups depending on the normality of the data.

Receiver's operating characteristic (ROC) curve was constructed to determine the discriminating efficacy of the circulating IL-10 between healthy individuals and patients with carotid disease and between patients with complicated and uncomplicated plaques.

A $P$ value $<0.05$ was considered statistically significant. All statistical calculations were performed with the IBM SPSS statistics version 20.

$\mathbf{A}$

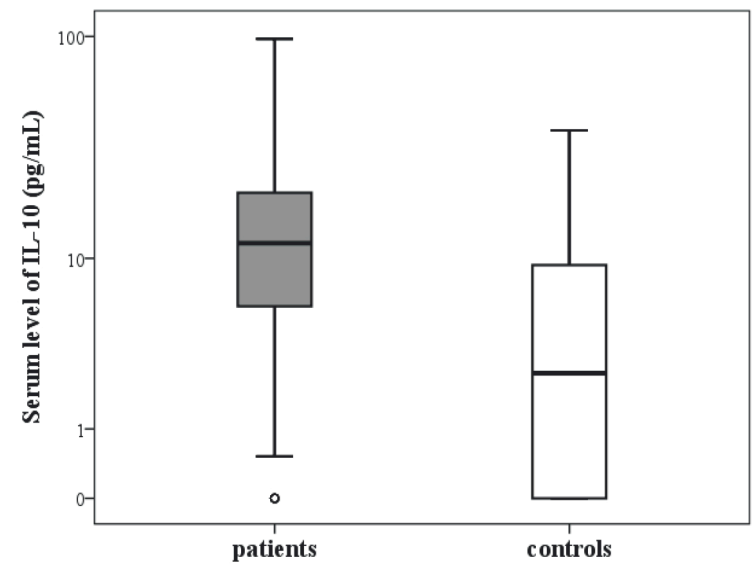

Figure 2. Serum levels of IL-10 in patients with carotid disease

A. Serum levels of IL-10 are increased in patients undergoing endarterectomy

B. ROC curve for IL-10 in healthy individuals versus patients with carotid atherosclerosis

\section{RESULTS}

Demographic, clinical and histologic plaque characteristics of patients with carotid atherosclerosis. Serum levels of $I L-10$ are increased in patients undergoing endarterectomy

This study of the 200 patients that underwent carotid endarterectomy was composed of 110 males (55\%) and 90 females (45\%), ranging from 43 to 83 years old (mean 66.5 $\pm 7.9)$. Our data show that average serum IL-10 level in healthy subjects was $7.2 \pm 1.8 \mathrm{pg} / \mathrm{ml}$. There was a significantly higher serum level of IL-10 in patients with carotid atherosclerosis compared with healthy subjects (Fig 1A). Patients undergoing endarterectomy had substantially higher average level of IL-10 $(18.7 \pm 3.2 \mathrm{pg} / \mathrm{ml} ; P=0.001)$ in comparison to healthy subjects. The ROC curve showed that serum IL-10 levels exhibited a good discriminatory efficacy between healthy individuals and patients with carotid disease $(\mathrm{AUC}=0.723, P=0.0001)$ (Fig 1B).

The patients were stratified into two groups based on the degree of carotid stenosis: those with less or equal to $70 \%$ or greater than $70 \%$ of stenosis as shown in Table 1 . There were no significant differences between the two groups of patients in terms of age, sex, cardiovascular risk factors: dyslipidemia, smoking status, and diabetes, presence of peripheral artery disease (PAD), coronary artery disease (CAD) or neurosymptoms, but there was a significantly higher number of patients with hypertension with carotid stenosis greater than $70 \%$.

Based on carotid plaque histological characteristics, patients were classified into groups IV, V and VI according to AHA criteria. Out of 200 analyzed carotid plaques, 13 were atherosclerotic plaques in the stage of atheroma (type IV lesion), 20 were at the stage of fibroatheroma (type Va), 30

B

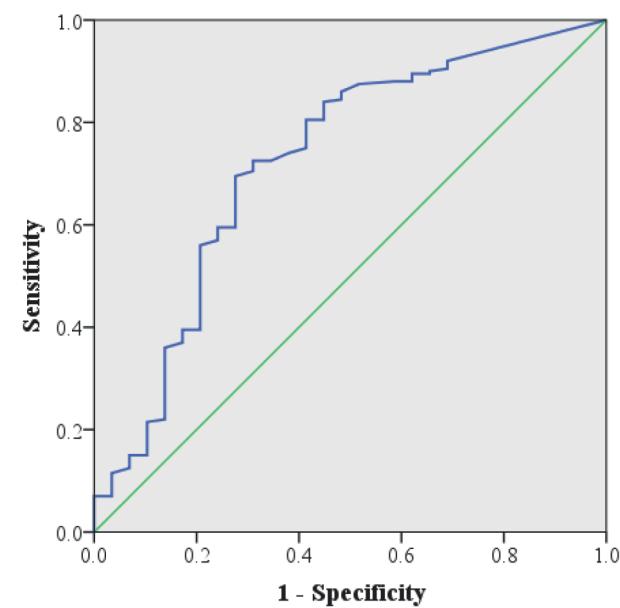

\begin{tabular}{|c|c|c|c|c|}
\hline \multicolumn{5}{|c|}{ Area Under the Curve } \\
\hline \multirow{2}{*}{ Area } & \multirow{2}{*}{$\begin{array}{l}\text { Std. } \\
\text { Errora }\end{array}$} & \multirow{2}{*}{$\begin{array}{l}\text { Asymp- } \\
\text { totic Sig.b }\end{array}$} & \multicolumn{2}{|c|}{$\begin{array}{c}\text { Asymptotic } 95 \% \\
\text { Confidence Interval }\end{array}$} \\
\hline & & & $\begin{array}{l}\text { Lower } \\
\text { Bound }\end{array}$ & $\begin{array}{l}\text { Upper } \\
\text { Bound }\end{array}$ \\
\hline .723 & .055 & .000 & .615 & .831 \\
\hline
\end{tabular}


Table 2. Serum levels of Interleukin-10: Comparison between patients with different clinical features

\begin{tabular}{|c|c|c|}
\hline Variable $^{a}$ & $\begin{array}{l}\text { Serum level of } I L-10(\mathrm{pg} / \mathrm{ml}) \\
n(\%)\end{array}$ & $P$ \\
\hline $\begin{array}{l}\text { Age } \\
\leq 65 \\
>65\end{array}$ & $\begin{array}{l}12.4(7.2-23.2) \\
92(47.4) \\
10.8(4.6-16.6) \\
102(52.6)\end{array}$ & .627 \\
\hline $\begin{array}{r}\text { Gender } \\
\text { Male } \\
\text { Female }\end{array}$ & $\begin{array}{l}12.3(7.3-22.2) \\
109(54.8) \\
11.0(3.9-17.1) \\
90(45.2)\end{array}$ & .520 \\
\hline $\begin{array}{r}\text { Smoking } \\
\text { Yes } \\
\text { No }\end{array}$ & $\begin{array}{l}11.3(5.6-20.19) \\
146(74.9) \\
13.2(6.3-20.4) \\
49(25.1)\end{array}$ & .701 \\
\hline $\begin{array}{r}\text { Diabetes Mellitus } \\
\text { Yes } \\
\text { No }\end{array}$ & $\begin{array}{l}11.0(4.0-22.8) \\
66(34.0) \\
12.0(6.4-19.8) \\
128(66.0)\end{array}$ & .551 \\
\hline $\begin{array}{r}\text { Hypertension } \\
\text { Yes } \\
\text { No }\end{array}$ & $\begin{array}{l}11.6(5.7-20.2) \\
187(95.9) \\
12.5(8.5-29.7) \\
8(4.1)\end{array}$ & .658 \\
\hline $\begin{array}{r}\text { Degree of carotid stenosis } \\
\leq 70 \% \\
>70 \%\end{array}$ & $\begin{array}{l}9.9(6.2-18.6) \\
18(9.2) \\
12.3(5.7-21.4) \\
176(90.8)\end{array}$ & .839 \\
\hline $\begin{array}{r}\text { CAD } \\
\text { Present } \\
\text { Absent }\end{array}$ & $\begin{array}{l}15.7(7.9-25.6) \\
85(42.7) \\
9.4(4.8-15.5) \\
114(57.3) \\
\end{array}$ & $.031^{b}$ \\
\hline $\begin{array}{r}\text { PAD } \\
\text { Present } \\
\text { Absent }\end{array}$ & $\begin{array}{l}9.8(4.2-16.7) \\
26(13.1) \\
12.2(6.0-16.7) \\
173(86.9) \\
\end{array}$ & .524 \\
\hline $\begin{array}{r}\text { Neurosymptoms } \\
\text { Yes } \\
\text { No }\end{array}$ & $\begin{array}{l}11.0(5.4-17.5) \\
111(55.8) \\
13.4(6.1-23.7) \\
88(44.2)\end{array}$ & .918 \\
\hline
\end{tabular}

PAD, peripheral artery disease; $C A D$, coronary artery disease;

${ }^{a}$ Values are presented as median and range/25th -75 th percentiles or absolute numbers with calculated percentage

${ }^{b}$ Statistically significant (Mann-Whitney U test; $\mathrm{P}<0.05$ ).

were at the stage of fibroatheroma with calcifications $(\mathrm{Vb}$ lesion), 67 were fibrous plaques (type Vc lesion), 51 were at the stage of ruptured atheroma with calcifications (type VIa) and 16 plaques were atheroma complicated by previous rupture, thrombosis or hemorrhage (type VIb lesion) and 3 plaques were VIc (Fig 2B). Table 1 shows morphological plaque features and analyzes revealed no significant differences between the two groups in terms of plaque inflammatory infiltration, intraplaque calcification, hemorrhage and rupture and carotid plaque types. Representative images of carotid plaque types are shown in Fig 2A.

\section{Serum levels of Interleukin-10 in patients with different clinical features}

There were no significant differences in serum levels of IL-10 in patients in terms of age, sex, cardiovascular risk factors: hypertension, dyslipidemia, smoking status and diabetes, and the degree of carotid stenosis or neurosymptoms. Patients with CAD had significantly higher serum levels of IL-10 in comparison to patients without CAD $(25.8 \pm 7.1$ $\mathrm{pg} / \mathrm{ml}$ vs. $12.1 \pm 1.2, P=.031$ ), while patients with PAD has similar serum levels of IL-10 compared to those without PAD. These results are summarized in Table 2.

\section{Serum levels of IL-10 are related to histological features of carotid plaques}

There were no significant differences in serum levels of IL-10 in patients in terms of the presence of intraplaque inflammation, hemorrhage, rupture or calcification (Table $3)$. There was a significant difference in serum levels of IL10 among patients with different types of carotid plaques according to AHA criteria as shown in Fig 3. When serum IL-10 level was analyzed in relation to histological features of the carotid plaques the highest level of IL-10 was found in the group of patients with fibrotic plaques $(26.8 \pm 9.0$ $\mathrm{pg} / \mathrm{ml})$, followed by those with fibroatheromatous plaques $(18.0 \pm 3.5 \mathrm{pg} / \mathrm{ml})$. Patients with fibroatheroma complicated with hemorrhage had serum level of IL-10 of $15.1 \pm 2.4$ $\mathrm{pg} / \mathrm{ml}$; patients with ruptured atheroma with calcifications $13.1 \pm 1.6 \mathrm{pg} / \mathrm{ml}$, patients with fibroatheroma with calcifications $11.5 \pm 3.3 \mathrm{pg} / \mathrm{ml}$ and the lowest serum level of IL-10 was detected in the group of patients with atheroma complicated by previous thrombosis $(10.3 \pm 2.3 \mathrm{pg} / \mathrm{ml})$ and

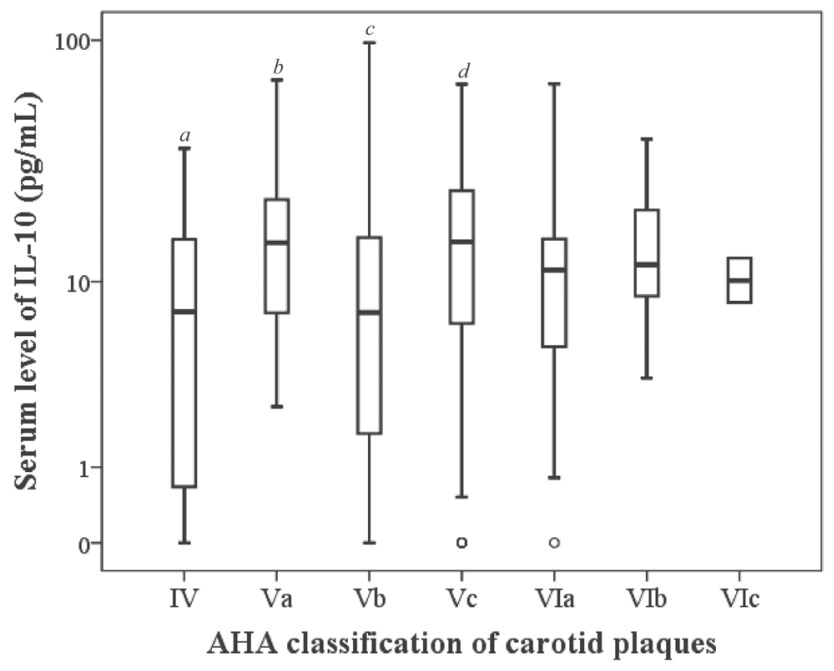

Figure 3. Circulating IL-10 levels depend on carotid plaque type

A. Serum IL-10 significantly differ among patients with different types of carotid plaques (AHA classification)); ${ }^{a}$ type IV vs. Vc $P$ $=.081 ;{ }^{b}$ type Va vs. $\mathrm{Vb} P=.014 ;{ }^{c}$ type $\mathrm{Vb}$ vs. $\mathrm{Vc} P=.004 ;{ }^{c}$ type $\mathrm{Vb}$ vs. VIb $P=.035 ;{ }^{d}$ type Vc vs. VIa $P=.068$ 
atheroma $(10.9 \pm 3.2 \mathrm{pg} / \mathrm{ml})$. The results of the circulating IL-10 levels between patients with different types of carotid plaques are summarized in Table 3.

Next, we analyzed the difference in serum IL-10 levels in patients with stable and unstable carotid plaques. Patients were divided according to the presence of stable carotid plaques (fibrous plaques and fibroatheroma) (87 patients; $43.5 \%$ ) and those with unstable carotid plaques (atheroma, atheroma and fibroatheroma with complications including calcification, hemorrhage, rupture or thrombosis (113 patients; 56.5\%)). Serum level of IL-10 was significantly higher in patients with stable plaques compared to those with signs of plaque instability $(24.8 \pm 7.0$ vs. $14.0 \pm 1.8 \mathrm{pg} / \mathrm{ml} ; P=0.005$ ).

One of the clinical criteria for performing elective carotid artery surgery is stenosis of internal carotid artery (ICA) greater than $70 \%$. The group of patients with $<70 \%$ stenosis had mean IL-10 serum level $16.2 \pm 5.07 \mathrm{pg} / \mathrm{ml}$, while patients with $>70 \%$ stenosis had mean IL-10 level $18.30 \pm 3.59 \mathrm{pg} / \mathrm{ml}$, without statistically significant differ ence between groups $(P>0.05)$.

Patients undergoing endarterectomy were grouped in relation to the presence or absence of neurological symptomatology prior to surgery. Patients with neurosymptoms had mean serum IL-10 level of $18.30 \pm 5.50 \mathrm{pg} / \mathrm{ml}$, while patients without previous neurological symptomatology had mean serum IL-10 level of $17.62 \pm 1.77 \mathrm{pg} / \mathrm{ml}$. Again, no statistically significant difference was observed $(\mathrm{P}>0.05)$.

\section{Circulating IL-10 differentiate patients with complicated plaques from patients with uncomplicated plaques}

Patients were divided in two groups based on the histological characteristics of plaques. Group of patients with any form of complication in the plaque itself, like the rupture of the plaque, hemorrhage in the plaque, recanalization of the plaque or the thrombosis of the plaque, and also presence of large lipid core with thin fibrous cap or calcification and patients whose plaques were without aforementioned features.

Serum IL-10 concentrations were significantly lower in patients with complicated plaques as compared to the patients with uncomplicated plaques $(13.03 \pm 1.36 \mathrm{pg} / \mathrm{ml}$ vs. $23.04 \pm 6.15 \mathrm{pg} / \mathrm{ml} ; P=.035$ ) (Fig $4 \mathrm{~A}$ ). The ROC curve for serum IL-10 levels showed a significant discriminatory efficacy between patients with complicated plaques from patients with uncomplicated plaques $(\mathrm{AUC}=0.413, P=$ 0.035) (Fig 4B).

\section{DISCUSSION}

The results obtained in this study imply that IL-10 may have substantial influence on the evolution of atherosclerotic process in carotid arteries. That is, our work shows higher levels of circulating IL-10 in the group of patients with carotid disease in comparison to healthy subjects.
Table 3. Serum levels of Interleukin-10: Comparison between patients with different histological features of carotid plaques

\begin{tabular}{|c|c|c|}
\hline Carotid plaque histolog $y^{a}$ & $\begin{array}{l}\text { Serum level of IL- } \\
10(\mathrm{pg} / \mathrm{ml}) \\
n(\%)\end{array}$ & $P$ \\
\hline $\begin{array}{r}\text { Intraplaque inflammatory infiltration } \\
\text { Present } \\
\text { Absent }\end{array}$ & $\begin{array}{l}21.4(13.8-26.8) \\
7(3.9) \\
(8.0-70.2) \\
192(96.1) \\
\end{array}$ & .640 \\
\hline $\begin{array}{r}\text { Intraplaque calcification } \\
\text { Present } \\
\text { Absent }\end{array}$ & $\begin{array}{l}11.1(3.8-15.7) \\
73(36.7) \\
13.0(6.6-23.4) \\
126(63.3)\end{array}$ & .189 \\
\hline $\begin{array}{r}\text { Intraplaque hemorrhage } \\
\text { Present } \\
\text { Absent }\end{array}$ & $\begin{array}{l}13.0(8.6-21.8) \\
17(8.5) \\
11.6(5.4-20.0) \\
182(91.5)\end{array}$ & .808 \\
\hline $\begin{array}{r}\text { Rupture of plaque } \\
\text { Present } \\
\text { Absent }\end{array}$ & $\begin{array}{l}11.1(6.5-15.5) \\
56(28.1) \\
12.5(5.7-23.0) \\
143(71.9)\end{array}$ & .351 \\
\hline $\begin{array}{r}\text { AHA classification of carotid plaques } \\
\text { IV } \\
\mathrm{Va} \\
\mathrm{Vb} \\
\mathrm{Vc} \\
\mathrm{VIa} \\
\mathrm{VIb} \\
\mathrm{VIc}\end{array}$ & $\begin{array}{l}7.3(0.3-18.0) \\
13(6.5) \\
14.7(7.3-23.00) \\
20(10.0) \\
7.3(1.3-15.6) \\
30(15) \\
14.9(6.4-24.6) \\
67(33.7) \\
11.3(4.8-15.7) \\
51(25.5) \\
11.9(8.5-21.9) \\
16(8.0) \\
10.4(8.1-12.6) \\
3(1.5) \\
\end{array}$ & $.041^{b}$ \\
\hline $\begin{array}{l}{ }^{a} \text { Values are presented as median and rang } \\
\text { absolute numbers with calculated percent } \\
{ }^{5} \text { Statistically significant (Mann-Whitney } \\
\mathrm{P}<0.05 \text { ). }\end{array}$ & $\begin{array}{l}\text { e/25th }-75 \text { th perce } \\
\text { age } \\
\text { J and Kruskal-Walli }\end{array}$ & sor \\
\hline
\end{tabular}

Recent papers show association between reduced serum IL-10 levels and the risk of cerebral infarction (31). Study of Ambrosius W. et al (32) show lower levels of IL-10 in patients which had higher values of carotid intima-media thickness (IMT), which is an ultrasound marker of the level of atherosclerosis. Our results are not in agreement with these studies. In our study patients who underwent surgical repair of carotid artery had significantly higher serum levels of IL-10 when compared to control subjects. Our findings are in line with recent evidence of higher levels of IL-6 and IL-10 in patients with progressive carotid sclerosis (33). Moreover, in this study IL-6 and IL-10 were found to be independent variables for the unfavorable dynamics of changes in the morphology of atherosclerotic carotid plaques. Atherosclerotic plaques may be influenced by alterations in systemic levels of circulating cytokines including IL-10. We can conclude that, according to our data, 
A

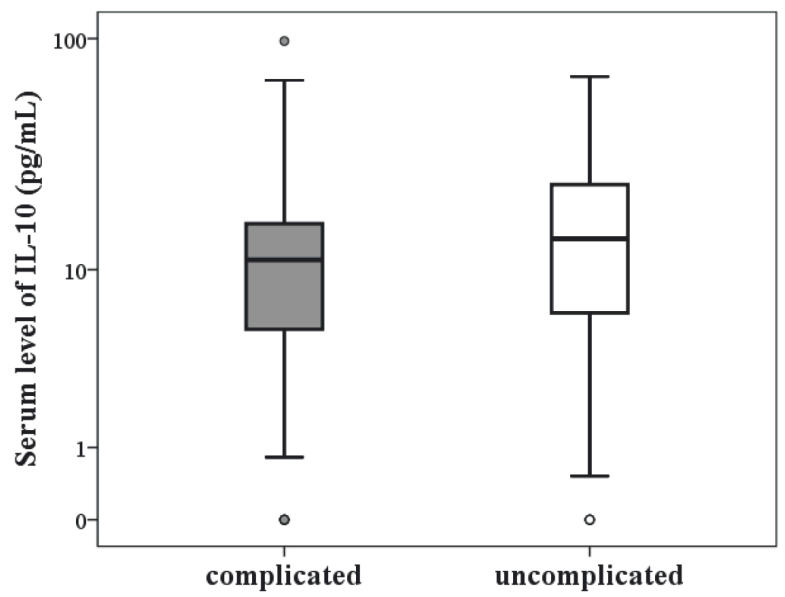

Figure 4. Serum levels of IL-10 in patients with complicated and uncomplicated plaques

A. Serum levels of IL-10 are increased in patients with uncomplicated plaques

B. ROC curve for serum IL-10 in patients with complicated and uncomplicated plaques
B

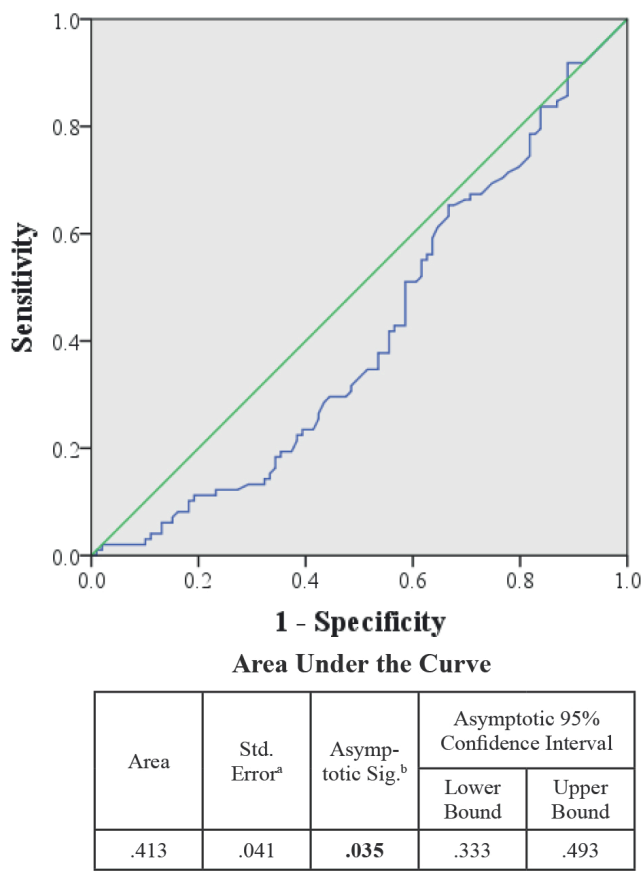

higher circulating levels of IL-10 do not reflect atheroprotective action in carotid artery disease.

Our results show that stage of carotid artery disease and structure of plaque does depend on the circulating level of IL-10. Our paper shows that patients with stable plaques enriched with fibrous tissue, like fibroma and fibroatheroma (type Va and Vc lesions) had significantly higher levels of circulating IL-10 than patients who had unstable plaques. This may be the reflection of the propensity of IL-10 to induce Th2 immune response in local milieu, and to drive tissue macrophages towards type 2 inflammatory response, and stimulation of tissue repair and activation of fibroblasts. This would potentially lead to beneficial outcome of atherosclerotic process since these types of plaques are less prone to rupture, then vulnerable plaques. They, however, do cause narrowing of blood vessel diameter, and in that way compromise inflow of blood to the brain. In the work of Pinderski et al, (22), decrease in accumulation of lipids in experimental model of atherosclerosis was observed, regardless of circulating levels of IL-10. Possible mechanisms might be imbalance between pro-inflammatory and anti-inflammatory cytokines.

Halvorsen et al (35) show, however, that IL-10 stimulates lipid accumulation in oxLDL treated macrophages and inhibits their apoptosis. When apoptosis is inhibited, there are less free cholesterol crystals and fatty acids which could potentially induce inflammatory response in local environment. When apoptosis is abundant, as shown in some recent papers, atherosclerotic plaque becomes more susceptible to rupture (36-38). In this way, as authors explain, IL-10 diminishes the size of necrotic core of atherosclerotic plaque. This may stabilize the plaque itself, making it less prone to rup- ture. It has been shown that IL-10 modulates lipid metabolism in macrophages, both by stimulating cholesterol uptake and efflux from cells (39). There are reports showing that efficient efflux of cholesterol is mostly confined to M2 macrophages, induced in Th2 immune response $(40,41)$. Our work also concurs with these findings, since we found higher levels of IL-10 in patients with uncomplicated plaques. We now may conclude that higher levels of IL-10 are related to plaque structure less prone to rupture, and, in that way, this cytokine may exert atheroprotective activity.

As mentioned above, numerous experimental data show atheroprotective role of IL-10 in highly controlled environment and in knock-out animals lacking IL-10, where it exerts unquestionable favorable influence on atherosclerotic process both through inhibition of inflammation, and by stimulation of restorative action of fibroblasts (21, 23-25). However, there are recent papers showing no benefit of IL10 in slowing down atherosclerotic process (42) in different animal models, the findings that reflect multifactorial background in atherogenesis. Also, experimental results cannot be simply translated to human pathology. This is shown in our findings that levels of IL-10 are significantly higher in patients with coronary artery disease, but not in patients with peripheral artery disease. It is well known that myocardial infarction and angina pectoris are accompanied by various alterations in levels of pro- and anti-inflammatory cytokines $(43,44)$. This may be due to the fact that myocardial disease may provoke systemic inflammatory response, as seen in severe bacterial infections, only without microbiological stimuli $(45,46)$. This type of systemic inflammation may sometimes occur in severe cerebral infarction, but never occurs during the development of atherosclerotic lesion. 
Moreover, it is well established that prognosis of atherosclerosis outcome relates more to the structure of atherosclerotic lesion, its cellular content and level of inflammation within the plaque (47). These characteristics determine whether undesirable event may occur, with possible fatal consequences, disabilities, prolonged hospitalization, and need for various medical interventions. Degree of artery stenosis remains one of stable indications for medical interventions, since narrowing of blood vessel occurs independently from plaque structure, and different types of plaques may cause the same blood flow impairment if there is similar degree of stenosis.

All these facts imply that process of atherosclerosis may be influenced by altering immune reactions which could possibly lead to preferred outcome, stabilization of atherosclerotic lesion and reduction of its size. There are pioneer projects towards this aim, and results need to be evaluated only after longtime follow-up (48).

This work clearly shows that differences in IL-10 serum levels reflect differences in types of atherosclerotic lesions, rather than size of the lesion. We have also shown that different clinical parameters do not relate to the degree of stenosis or type of atherosclerotic lesion. According to our findings, IL-10 could be employed in atheroprotective manner, as the highest serum IL-10 levels were found in patients with uncomplicated plaques.

Atherosclerotic process results from numerous environmental and intrinsic factors, and represents the dynamical and complex process which pathogenesis is only partly defined. Investigating the roles of cytokines in the development, growth and destabilization of atherosclerotic lesions is necessary in search of drugs that by affecting the concentration of certain cytokines may be important for inhibition of atherosclerosis progression.

\section{ACKNOWLEDGEMENT}

The authors thank Irena Tanaskovic (Faculty of medical sciences, University of Kragujevac) for help in histopathologic analysis of carotid plaques. The authors also thank Nikola Jankovic (Faculty of medical sciences, University of Kragujevac) for help in statistical analyses and Aleksandar Ilic (Faculty of medical sciences, University of Kragujevac) for technical assistance. We thank Vera Maravic-Stojkovic for help in collecting the samples. We thank Miljan Nedeljkovic for excellent technical assistance.

This work was supported by grants from the Serbian Ministry of Science and Technological Development (ON175103 and ON175069), Serbia and Faculty of Medical Sciences, University of Kragujevac, Serbia (Grant no. JP 07-14).

\section{CONFLICT OF INTEREST}

The authors declare no conflict of interest.

\section{SHORT TITLE:}

IL-10 in carotid atherosclerosis

\section{REFERENCES:}

1. Jonasson, L., Holm, J., Skalli, O., Bondjers, G., \& Hansson, G. K. (1986). Regional accumulations of T cells, macrophages, and smooth muscle cells in the human atherosclerotic plaque. Arteriosclerosis, Thrombosis, and Vascular Biology, 6(2), 131-138. doi:10.1161/01.atv.6.2.131

2. Epstein, F. H., \& Ross, R. (1999). Atherosclerosis - An Inflammatory Disease. New England Journal of Medicine, 340(2), 115-126. doi:10.1056/ nejm199901143400207

3. Libby, P., Lichtman, A., \& Hansson, G. (2013). Immune Effector Mechanisms Implicated in Atherosclerosis: From Mice to Humans. Immunity, 38(6), 1092-1104. doi:10.1016/j.immuni.2013.06.009

4. Tuomisto, K., Jousilahti, P., Sundvall, J., Pajunen, P., \& Salomaa, V. (2006). C-reactive protein, interleukin-6 and tumor necrosis factor alpha as predictors of incident coronary and cardiovascular events and total mortality. A population-based, prospective study. Thrombosis and Haemostasis. doi:10.1160/th05-08-0571

5. Breland, U. M., Michelsen, A. E., Skjelland, M., Folkersen, L., Krohg-Sørensen, K., Russell, D., Ueland, T., Yndestad, A., Paulsson-Berne, G., Damås, J.K., Oie, E., Hansson, G.K., Halvorsen, B., \& Aukrust, P. (2010). Raised MCP-4 levels in symptomatic carotid atherosclerosis: an inflammatory link between platelet and monocyte activation. Cardiovascular Research, 86(2), 265-273. doi:10.1093/cvr/cvq044

6. Martin-Ventura, J. L., Madrigal-Matute, J., MunozGarcia, B., Blanco-Colio, L. M., Oostrom, M. V., Zalba, G., Fortuño, A., Gomez-Guerrero, C., Ortega, L., Ortiy, A., Diey, J., \& Egido, J. (2009). Increased CD74 expression in human atherosclerotic plaques: contribution to inflammatory responses in vascular cells. Cardiovascular Research, 83(3), 586-594. doi:10.1093/cvr/cvp141

7. Szodoray, P., Timar, O., Veres, K., Der, H., Szomjak, E., Lakos, G., Aleksza, M., Nakken, B., Szegedi, G. \& Soltesz, P. (2006). Th1/Th2 Imbalance, Measured by Circulating and Intracytoplasmic Inflammatory $\mathrm{Cy}-$ tokines - Immunological Alterations in Acute Coronary Syndrome and Stable Coronary Artery Disease. Scandinavian Journal of Immunology, 64(3), 336-344. doi:10.1111/j.1365-3083.2006.01816.x

8. Yamagami, H. (2005). Associations of Serum IL-18 Levels With Carotid Intima-Media Thickness. Arteriosclerosis, Thrombosis, and Vascular Biology, 25(7), 1458-1462. doi:10.1161/01.atv.0000168417.52486.56

9. Elkind, M. S., Rundek, T., Sciacca, R. R., Ramas, R., Chen, H., Boden-Albala, B., Rabbani, L., Sacco, R. L. (2005). Interleukin-2 levels are associated with carotid artery intima-media thickness. Atherosclerosis, 180(1), 181-187. doi:10.1016/j.atherosclerosis.2004.11.015 
10. Heeschen, C. (2003). Serum Level of the Antiinflammatory Cytokine Interleukin-10 Is an Important Prognostic Determinant in Patients With Acute Coronary Syndromes. Circulation, 107(16), 2109-2114. doi:10.1161/01.cir.0000065232.57371.25

11. Silveira, A., McLeod, O., Strawbridge, R. J., Gertow, K., Sennblad, B., Baldassarre, D., et al. (2015). Plasma IL-5 concentration and subclinical carotid atherosclerosis. Atherosclerosis, 239(1), 125-130. doi.org/10.1016/j. atherosclerosis.2014.12.046

12. Fiorentino, D. F. Bond MW, \& Mosmann TB. (1989). Two types of mouse T helper cell. IV. Th2 clones secrete a factor that inhibits cytokine production by Th1 clones. Journal of Experimental Medicine, 170(6), 2081-2095. doi:10.1084/jem.170.6.2081

13. Malefyt, R. D. (1991). Interleukin 10(IL-10) inhibits cytokine synthesis by human monocytes: an autoregulatory role of IL-10 produced by monocytes. Journal of Experimental Medicine, 174(5), 1209-1220. doi:10.1084/jem.174.5.1209

14. Mosser, D. M., \& Zhang, X. (2008). Interleukin-10: new perspectives on an old cytokine. Immunological Reviews, 226(1), 205-218. doi:10.1111/j.1600065x.2008.00706.x

15. Pestka, S., Krause, C.D., Sarkar, D., Walter, M.R., Shi, Y. \& Fisher, P.B. (2004) Interleukin-10 and Related Cytokines and Receptors. Annual Review of Immunology, 22, 929-979.

16. Akdis, C. A. Joss A., Akdis M., Faith A. \& Blaser K. A. (2000). A molecular basis for T cell suppression by IL10: CD28-associated IL-10 receptor inhibits CD28 tyrosine phosphorylation and phosphatidylinositol 3-kinase binding. The FASEB Journal. doi:10.1096/fj.99-0874fje

17. Opp, M., Smith, E., \& Hughes, T. (1995). Interleukin-10 (cytokine synthesis inhibitory factor) acts in the central nervous system of rats to reduce sleep. Journal of Neuroimmunology, 60(1-2), 165-168. doi:10.1016/01655728(95)00066-b

18. Ma, X., Aste-Amezaga, M., Gri, G., Gerosa, F., \& Trinchieri, G. (1997). Immunomodulatory Functions and Molecular Regulation of IL-12. Chemical Immunology and Allergy IL-12, 1-22. doi:10.1159/000058687

19. Varma, T. K., Toliver-Kinsky, T. E., Lin, C. Y., Koutrouvelis, A. P., Nichols, J. E., \& Sherwood, E. R. (2001). Cellular Mechanisms That Cause Suppressed Gamma Interferon Secretion in Endotoxin-Tolerant Mice. Infection and Immunity, 69(9), 5249-5263. doi:10.1128/ iai.69.9.5249-5263.2001

20. Mocellin, S. Panelli M.C., Wang E., Nagorsen D. \& Marincola F.M. (2003). The dual role of IL-10. Trends in Immunology, 24(1), 36-43. doi:10.1016/s14714906(02)00009-1

21. Sikka, G., Miller, K. L., Steppan, J., Pandey, D., Jung, S. M., Fraser, C. D., et al. (2013). Interleukin 10 knockout frail mice develop cardiac and vascular dysfunction with increased age. Experimental Gerontology, 48(2), 128-135. doi:10.1016/j.exger.2012.11.001
22. Pinderski, L. J. (2002). Overexpression of Interleukin-10 by Activated $\mathrm{T}$ Lymphocytes Inhibits Atherosclerosis in LDL Receptor-Deficient Mice by Altering Lymphocyte and Macrophage Phenotypes. Circulation Research, 90(10), 1064-1071. doi:10.1161/01.res.0000018941.10726.fa

23. Caligiuri, G., Rudling, M., Ollivier, V., Jacob, M.-P., Michel, J.-B., Hansson, G. K., \& Nicoletti, A. (2003). Interleukin-10 Deficiency Increases Atherosclerosis, Thrombosis, and Low-density Lipoproteins in Apolipoprotein E Knockout Mice. Molecular Medicine, 9(12), 10-17.

24. Han, X., Kitamoto, S., Wang, H., \& Boisvert, W. A. (2010). Interleukin-10 overexpression in macrophages suppresses atherosclerosis in hyperlipidemic mice. The FASEB Journal, 24(8), 2869-2880. doi:10.1096/ fj.09-148155

25. Yoshioka, T., Okada, T., Maeda, Y., Ikeda, U., Shimpo, M., Nomoto, T. et al. (2004). Adeno-associated virus vector-mediated interleukin-10 gene transfer inhibits atherosclerosis in apolipoprotein E-deficient mice. Gene Therapy, 11(24), 1772-1779. doi:10.1038/ sj.gt.3302348

26. Bancroft JD \& Gamble M. (2002). Theory and practice of histological techniques. 5th edition. Churchill Livingstone, Edeinburgh, London, New York, Oxford.

27. Stary H.C., Chandler A.B., Dinsmore R.E., Fuster V., Glagov S., Insull W. Jr, Rosenfeld M.E., Schwartz C.J., Wagner W.D. \& Wissler R.W. (1995). A Definition of Advanced Types of Atherosclerotic Lesions and a Histological Classification of Atherosclerosis. A Report From the Committee on Vascular Lesions of the Council on Arteriosclerosis, American Heart Association. Circulation; 92: 1355-1374.

28. Moreno, P. R. (2010). Vulnerable Plaque: Definition, Diagnosis, and Treatment. Cardiology Clinics, 28(1), 1-30. doi:10.1016/j.ccl.2009.09.008

29. Shindo, A., Tanemura, H., Yata, K., Hamada, K., Shibata, M., Umeda, Y. et al. Tomimoto, H. (2014). Inflammatory Biomarkers in Atherosclerosis: Pentraxin 3 Can Become a Novel Marker of Plaque Vulnerability. PLoS ONE, 9(6). doi:10.1371/journal.pone.0100045

30. Radosavljevic, G., Ljujic, B., Jovanovic, I., Srzentic, Z., Pavlovic, S., Zdravkovic, N., Milovanovic, M., Bankovic, D., Knezevic, M., Acimovic, LJ., \& Arsenijevic, N. (2010). Interleukin-17 may be a valuable serum tumor marker in patients with colorectal carcinoma. Neoplasma, 57(2), 135-144. doi:10.4149/neo_2010_02_135

31. Zhu, Y., Yang, H., Diao, Z., Li, Y., \& Yan, C. (2015). Reduced Serum Level of Interleukin-10 is Associated with Cerebral Infarction: A Case-Control and Meta-Analysis Study. Molecular Neurobiology, 53(4), 2698-2704. doi:10.1007/s12035-015-9368-y

32. Ambrosius, W., Kazmierski, R., Michalak, S., \& Kozubski, W. (2006). Anti-inflammatory cytokines in subclinical carotid atherosclerosis. Neurology, 66(12), 19461948. doi:10.1212/01.wnl.0000219808.28678.48 
33. Puz, P., \& Lasek-Bal, A. (2017). Repeated measurements of serum concentrations of TNF-alpha, interleukin- 6 and interleukin-10 in the evaluation of internal carotid artery stenosis progression. Atherosclerosis, 263, 97-103. doi:10.1016/j.atherosclerosis.2017.06.008

34. Verma, S. K., Garikipati, V. N., Krishnamurthy, P., Khan, M., Thorne, T., Qin, G., Losordo, D. W. \& Kishore, R. (2016). IL-10 Accelerates Re-Endothelialization and Inhibits Post-Injury Intimal Hyperplasia following Carotid Artery Denudation. Plos One, 11(1). doi:10.1371/ journal.pone.0147615

35. Halvorsen, B., Wæhre, T., Scholz, H., Clausen, O. P., Thüsen, J. H., Müller, F., Heimli, H., Tonstad, S., Hall, C., Frøland, S.S., Biessen, E.A., Damås, J.K. \& Aukrust, P. (2004). Interleukin-10 enhances the oxidized LDL-induced foam cell formation of macrophages by antiapoptotic mechanisms. Journal of Lipid Research, 46(2), 211-219. doi:10.1194/jlr.m400324-jlr200

36. Björkerud, S., \& Björkerud, B. (1996). Apoptosis is abundant in human atherosclerotic lesions, especially in inflammatory cells (macrophages and $\mathrm{T}$ cells), and may contribute to the accumulation of gruel and plaque instability. The American Journal of Pathology, 149(2), 367-380.

37. Davies, M. J. (1996). Stability and Instability: Two Faces of Coronary Atherosclerosis: The Paul Dudley White Lecture 1995. Circulation, 94(8), 2013-2020. doi:10.1161/01.cir.94.8.2013

38. Libby, P. (1995). Molecular Bases of the Acute Coronary Syndromes. Circulation, 91(11), 2844-2850. doi:10.1161/01.cir.91.11.2844

39. Han, X., \& Boisvert, W. A. (2014). Interleukin-10 protects against atherosclerosis by modulating multiple atherogenic macrophage function. Thrombosis and Haemostasis, 113(3), 505-512. doi:10.1160/th1406-0509

40. Chau, L., Lee, T., Yen, H., \& Pan, C. (1998). Role of interleukin-12 in development of atherosclerosis in apoe-deficient mice. Atherosclerosis, 136. doi:10.1016/ s0021-9150(97)84555-8

41. Tits, L. V., Stienstra, R., Lent, P. V., Netea, M., Joosten, L., \& Stalenhoef, A. (2011). Oxidized LDL enhances pro-inflammatory responses of alternatively activated M2 macrophages: A crucial role for Krüppel-like factor 2. Atherosclerosis, 214(2), 345-349. doi:10.1016/j. atherosclerosis.2010.11.018
42. Du, L., Dronadula, N., Tanaka, S., \& Dichek, D. A. (2011). Helper-Dependent Adenoviral Vector Achieves Prolonged, Stable Expression of Interleukin-10 in Rabbit Carotid Arteries but Does Not Limit Early Atherogenesis. Human Gene Therapy, 22(8), 959-968. doi:10.1089/hum.2010.175

43. Kosmala, W., Derzhko, R., Przewlocka-Kosmala, M., Orda, A., \& Mazurek, W. (2008). Plasma levels of TNF- $\alpha$, IL-6, and IL-10 and their relationship with left ventricular diastolic function in patients with stable angina pectoris and preserved left ventricular systolic performance. Coronary Artery Disease, 19(6), 375-382. doi:10.1097/mca.0b013e3282fc617c

44. Zhang, D.-F., Song, X.-T., Chen, Y.-D., Yuan, F., Xu, F., Zhang, M., Zhang, M.-D., Wang, W., Dai, J \& Lyu, S.Z. (2016). Prognostic performance of interleukin-10 in patients with chest pain and mild to moderate coronary artery lesions-an 8-year follow-up study. Journal of Geriatric Cardiology: JGC, 13(3), 244-251. doi. org/10.11909/j.issn.1671-5411.2016.03.012

45. Fang, L., Moore, X.-L., Dart, A. M., \& Wang, L.-M. (2015). Systemic inflammatory response following acute myocardial infarction. Journal of Geriatric Cardiology: JGC, 12(3), 305-312. doi.org/10.11909/j. issn.1671-5411.2015.03.020

46. Kozinski, M., Krzewina-Kowalska, A., Kubica, J., Żbikowska-Gotz, M., Dymek, G., Piasecki, R., Sukiennik, A., Grzesk, G., Bogdan, M., Chojnicki, M., Dziedziczko, A. \& Sypniewska, G. (2005). Percutaneous coronary intervention triggers a systemic inflammatory response in patients treated for in-stent restenosis - comparison with stable and unstable angina. Inflammation Research, 54(5), 187-193. doi:10.1007/ s00011-005-1342-0

47. Mallat, Z., Besnard, S., Duriez, M., Deleuze, V., Emmanuel, F., Bureau, M. F., et al. (1999). Protective Role of Interleukin-10 in Atherosclerosis. Circulation Research, 85(8). doi:10.1161/01.res.85.8.e17

48. Kimura T., Tse K., McArdle S., Gerhardt T., Miller J., Mikulski Z., Sidney J., Sette A., Wolf D., \& Ley K. (2017)-Atheroprotective vaccination with MHC-II-re-stricted ApoB peptides induces peritoneal IL-10-pro-ducing CD4 T cells. Am J Physiol Heart Circ Physiol. Apr 1;312(4):H781-H790. doi: 10.1152/ajpheart.00798. 2016. Epub 2017 Jan 13. PubMed PMID:28087520; PubMed Central PMCID: PMC5407161. 